\title{
Unemployment as a Medical and Social Problem and Incidence among Unemployed Young People
}

\author{
Samal Duisekova ${ }^{1}$, Zakira Kerimbayeva ${ }^{1}$, Adil' Mustafin ${ }^{2}$ (D), Akmaral Mussakhanova ${ }^{1}$, Assiya Turgambayeva ${ }^{1 *}$ (D), \\ Rimantas Stukas ${ }^{3}$ iD \\ ${ }^{1}$ Department of Public Health and Management, NJSC "Astana Medical University," Nur-Sultan, Kazakhstan; ${ }^{2}$ Department of \\ ENT-Diseases, NJSC "Astana Medical University," Nur-Sultan, Kazakhstan; ${ }^{3}$ Department of Public Health, Institute of Public \\ Health, Faculty of Medicine, Vilnius University, Vilnius, Lithuania
}

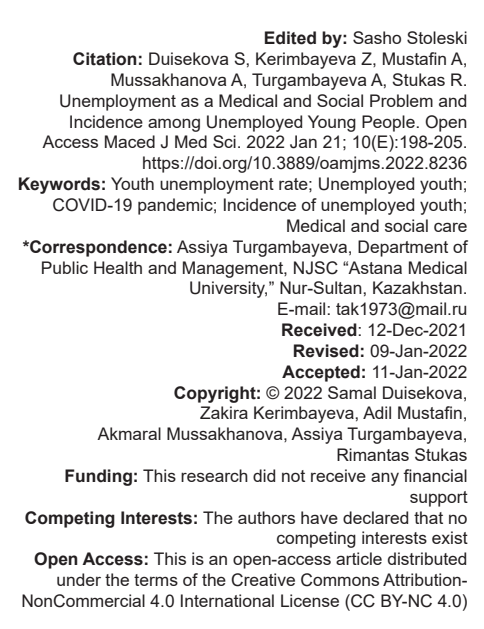

\section{Introduction}

Quality of life is a complicated concept that encompasses employment, productive activities that provide income and social status. In recent decades, the issues of the influence of socioeconomic factors on the level of incidence among the population have been widely studied; such factors include education, income, as well as the social status of the population [1], [2], [3], [4].

The situation with the apparition of the COVID-19 pandemic has become isolated, when socioeconomic instability manifests itself more clearly and exacerbates the situation with ensuring employment of the population [3], [4], [5], [6]. The world society does not have time to cope with the previous crises in the labor market, as the problem of employment and job loss appeared, associated with the introduced restrictive anti-epidemic measures to reduce the spread of coronavirus incidence [3], [6], [8], [10]. According to forecasts of the International Labor Organization (ILO), the current crisis will lead to an increase in the number of unemployed people according to a positive scenario by 5.3 million people, according to a negative scenario by 24.7 million people compared to previous years, while a decline in the labor market to this day is far from complete [6], [7], [9]. In particular, the informal employment sector suffered, where such categories of citizens as women, children, and youth turned out to be even more vulnerable, since their share of participation in the informal sector is higher than others [9], [10]. Modern youth has a more vivid transformation, often with high lability in the world of work; the NEET generation (neither work, nor study, nor improve their qualifications) has become a frequent occurrence among young people [11], [12]. This transformation has far-reaching implications for the health and quality of life of young people. Young people are more exposed to unemployment than other age groups, because they 
are emotionally labile; they are more likely to change their field of activity, and less competitive due to the lack of sufficient qualifications and experience [13], [14], [15]. According to research conducted by the ILO, the level of temporary employment among young people is twice as high as among adults, young people are more likely to be employed in irregular paid work without a contract [16].

Youth unemployment is recognized as one of the problems that creates social and economic problems for society at the global level [11], [16], [20]. In addition, mass youth unemployment exacerbates social problems, which can manifest itself in the form of such negative consequences as the emergence of major social conflicts, the criminalization of society, drug addiction, prostitution, and can also lead to suicide [17], [18], [19], which, as a result, leads to an increase in the number of young patients with venereal and other diseases. World statistics showed that the highest level of youth unemployment, according to data for 2021, was registered in South Africa (64.4\%), Angola (57.7\%), Nigeria (53.4\%), and further relatively high unemployment rates showed such countries such as Kosovo (49.9\%), Namibia (46.1\%), and Palestine $(43.1 \%)$. Furthermore, a high unemployment rate is typical for the countries of Southern Europe, in particular, Spain $(35.1 \%)$ and Italy $(27.7 \%)$. In contrast, the lowest unemployment rates were recorded in Germany (7.5\%), the Netherlands (7.3\%), South Korea $(7.1 \%)$, Japan $(4.2 \%)$, Kazakhstan (3.7\%), and Switzerland $(2.3 \%)$ [20].

In connection with the above, it follows that the structure of employment has changed from stable and predictable, to more flexible and uncertain due to the economic downturn, and this has led to an increase in the number of unemployed, which may have a greater impact on the health of the population [1], [2], [10], [14].

Many studies have shown that the harm of unemployment can be not only on the financial and psycho-emotional state of a person but also on his wellbeing [1], [15], [16], [17], [18], [19], [21], [22], [23]. For many years, the authors have been discussing the causal relationship between unemployment and deterioration in health, and there is also a tendency for young people with health problems to have problems getting a new job [23], [24], [25], [26]. Nevertheless, the literary sources about the relationship between unemployment and the state of health of young people are contradictory; the greatest controversy arises over the causal relationship between these processes [23], [27]. Some authors cite data that unemployment arises due to poor health of the proposed workers during selection for work. Along with this, people who have been unemployed for a long time for reasons not associated with any diseases, for example, less often undergo preventive examinations, have stress, limitation of material and financial resources for maintaining good health, poor nutrition, limitation in the availability of medical insurance all lead to a deterioration in health [27], [28], [29]. Plus, the adverse effects of unemployment are also observed for the relatives of young people [23], [29], [30].

A number of countries in the world are wondering about the impact of unemployment on the health of young people, and the degree of influence of such factors as economic recessions in Sweden, political decisions in the form of reforms in Germany is being studied [3], [30], [31] [32]. The most active studies on the impact of youth unemployment were carried out in Sweden [3], the Netherlands, where a reliable relationship was found between the impact of unemployment on the physical and mental health of young people.

Furthermore, a number of works by foreign authors indicate the relevance of the problem of unemployment impact on the mental state of young people [33], [34], [35], [36], [37], [38], [39]. Changes arise in mental health during prolonged exposure to stress as a result of the impossibility of employment at a decent job, pressure from relatives, the influence of bad habits [30], [40], [41]. Researchers from the Department of Public Health (Rotterdam, The Netherlands) suggest that re-employment of the unemployed for paid work can be a powerful means of improving public health, in particular mental health, as well as improving the quality of life [42]. The impact of unemployment on mental health was found when looking at cohort studies, where unemployment is perceived as a factor influencing health status, leading to stress, persistent feelings of guilt and low self-esteem, and therefore dissatisfaction with life [43].

Historically, unemployment has been associated with a variety of physical and psychological consequences, such as alcohol and cigarette consumption, low selfesteem, and life satisfaction [44], [45], [46]. In addition to mental health, unemployment also adversely affects the physical health of young people [47], [48], [49]. Youth unemployment as a chronic disease has a number of complications [50], [51], [52], which are exacerbated by the lifestyle factors of an unemployed young person, including an irregular regime and nutrition, and an increased stressful environment. An American study examined the hypothesis that unemployed people have a higher risk of cardiovascular disease [48], [49]. All models showed that the presence of the unemployed was significantly associated with a higher level of depressive symptoms and a lower level of physical activity. Compared to their colleagues, unemployed participants had lower levels of systolic blood pressure [49].

Therefore, we consider that the study of the relationship between unemployment and incidence among young people, taking into account other indicators of social well-being makes sense [50], [51].

The aim of the study was to examine the status of employment and the incidence among young people. 


\section{Materials and Methods}

We searched PubMed/Medline, Science Direct, Web of Science, and Scopus (July 2021) for studies focused on the impact of youth unemployment on the health of the population aged 18-29. After checking the titles and abstracts of 591 articles taken from four electronic databases, 123 articles remained for full-text reading. 51 studies of these met the inclusion criteria and were assessed for methodological quality. There is more research on the relationship between unemployment and health than between precarious employment and health (43 and 23, respectively). The overwhelming majority of studies (44) found support for the hypothesis of social causation, with the most common health outcomes being mental disorders, health risk behavior, poor quality of life, and occupational injuries.

The data of the national database of the Bureau of Statistics of Kazakhstan and the statistical data of the ILO for the period from 2015 to 2020 were studied.

As part of a cross-sectional study, a questionnaire was sent to unemployed young people in the number of 600 people aged 18-29, living in cities and villages of Kazakhstan in 2021. The questionnaire was approved by LEC. Both working and unemployed young people took part in the survey, where the first were as a control group. Gender, age, place of residence, educational level of the respondent and his parents, and previous health status were used as covariates in our analysis. The survey consisted of 42 questions, 17 of which were of a general nature, 25 were aimed at studying the impact of unemployment on the health of young people.

The questionnaires were completed online - 518, in person - 18. A t-test was performed to determine whether there was a significant difference between personal or virtual responses, and it was found that there were no differences in these responses. Therefore, it was decided to revise the data together. Participants were recruited through a variety of channels, including employment centers, youth policy departments, parties, non-governmental organizations, online forums, and messengers.

The study involved 536 people, among whom women $-69.2 \%$, men $-30.8 \%$. The average age of the participants was $26.0 \pm 6.34$. The research participants were people from all regions of Kazakhstan, most (42\%) from the city of Nur-Sultan, $14 \%$ from the Akmola region. Socio-demographic data are presented in Table 1.

The collected data were statistically processed using the Jamovi 1.6.23 software. The calculation of the main indicators of descriptive and analytical statistics has been carried out. Assessment of the differences between the incidence rates of unemployed and working youth and determination of the presence or absence of a relationship between health and incidence in unemployed youth.
Table 1: Socio-demographic data of respondents

\begin{tabular}{ll}
\hline Characteristics & $\mathrm{N}(\%)$ \\
\hline Gender & \\
Male & $165(30.8)$ \\
Female & $371(69.2)$ \\
Marital status & \\
Married & $219(40.9)$ \\
Single & $131(24.4)$ \\
Prefer not to answer & $4(0.7)$ \\
Place of residence & \\
Village & $65(12.1)$ \\
City & $464(86.6)$ \\
Prefer not to answer & $7(1.3)$ \\
Social status & \\
Employed & $234(43.7)$ \\
Unemployed/student & $86(16.0)$ \\
Unemployed/not student & $125(23.3)$ \\
Employed/student & $91(17.0)$ \\
Educational background & \\
Primary school & $10(1.9)$ \\
Incomplete secondary education & $15(2.8)$ \\
Specialized secondary education (specialized school, courses) & $41(7.6)$ \\
Secondary vocational education (technical school, college) & $91(17.0)$ \\
Undergraduate or equivalent level & $246(45.9)$ \\
Master's, specialist's degree or equivalent level & $114(21.3)$ \\
Postgraduate/Doctoral studies or equivalent level & $12(2.2)$ \\
Prefer not to answer & $7(1.3)$ \\
Mother's educational background & $9(1.7)$ \\
Primary school & $30(5.6)$ \\
Incomplete secondary education & $85(15.9)$ \\
Specialized secondary education (specialized school, courses) & $130(24.3)$ \\
Secondary vocational education (technical school, college) & $177(33.0)$ \\
Undergraduate or equivalent level & $49(9.1)$ \\
Master's, specialist's degree or equivalent level & $15(2.8)$ \\
Postgraduate/Doctoral studies or equivalent level & $41(7.6)$ \\
Prefer not to answer & $12(2.2)$ \\
Father's educational background & $35(6.5)$ \\
Primary school & $88(16.4)$ \\
Incomplete secondary education & $128(23.9)$ \\
Specialized secondary education (specialized school, courses) & $148(27.6)$ \\
Secondary vocational education (technical school, college) & $48(9.0)$ \\
Undergraduate or equivalent level & $8(1.5)$ \\
Master's, specialist's degree or equivalent level & $69(12.9)$ \\
Postgraduate/Doctoral studies or equivalent level & \\
Prefer not to answer & \\
\hline & \\
& \\
\hline
\end{tabular}

Among men, the share of unemployed youth was $24.8 \%$, while among women $-22.6 \%$, however, no significant differences were found $(p=0.578)$. Furthermore, there were no significant differences in the level of unemployment by marital status $(p=0.462)$. The largest number of unemployed youth was observed among citizens living in rural areas $(21.6 \%)$, moreover, $41.6 \%$ of rural youth were unemployed $(p<0.05)$.

\section{Results and Discussion}

Based on the data studied, it is noted that in recent years the labor market has been characterized by instability and lability. The TOP-10 countries with the highest and lowest overall unemployment rate in the world at the end of 2020 are shown in Figure 1.

According to ILO researchers, the low unemployment rates can be explained by the fact that the data are not properly recorded.

Gender inequality in the labor market remains an important aspect in the phenomenon of unemployment. According to official ILO data, Palestine, Iraq, and South Africa are the leaders in female unemployment and have rates of $41.14 \%, 30.59 \%$, and $30.50 \%$, respectively, while the highest rates for 


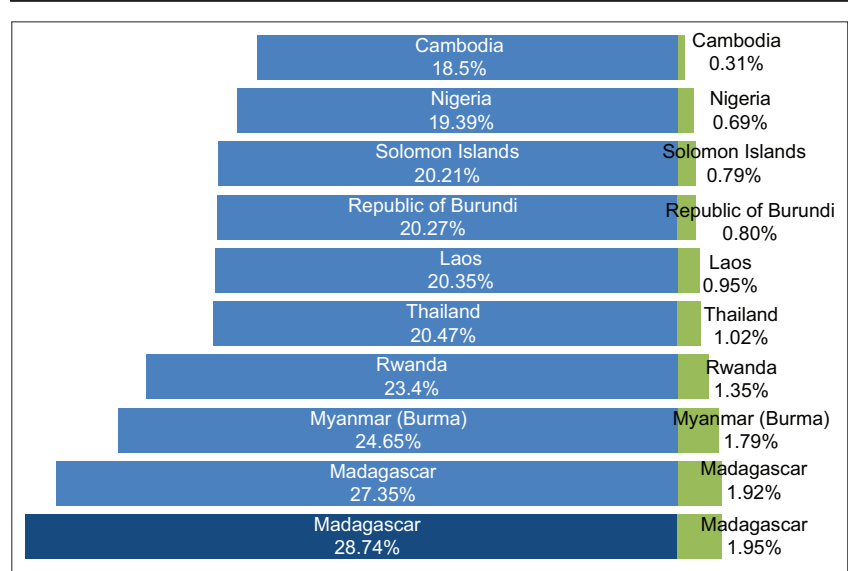

Figure 1: Countries with the highest and lowest level of overall unemployment in the world in 2020 according to the International Labor Organization

male unemployment are in South Africa - $26.68 \%$, Palestine - 21.32\%, Namibia - 20.94\% for 2020 .

Such data show that in the world there are significantly fewer young women in the labor market than men, and their unemployment rate is higher than that of men.

Despite conducted political activities, too many young people remain unemployed. In Figure 2 shows, the rate of youth unemployment in the world from 2015 to 2020 in dynamics. According to the ILO, young people belong to such a group that will be quite severely affected by the pandemic, both in the short- and longterm, which enhances this effect and the fact that, even before the situation with COVID-19, young people have already faced significant problems in relation to employment, more often such experience is described in the countries of Europe and as can be seen in the following Figure 2, the country with the highest level of youth unemployment is Italy.

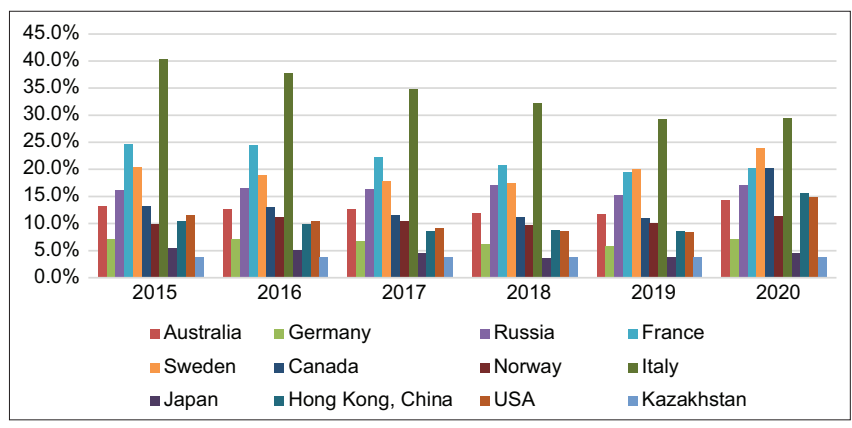

Figure 2: The level of youth unemployment in the world from 2015 to 2020 based on the materials of the International Labor Organization

Kazakhstan ranks $116^{\text {th }}$ among 188 countries in terms of unemployment, where the overall unemployment rate is $4.9 \%$, among men $4.2 \%$, and among women $5.6 \%$. According to the official data of the Committee on Statistics of the Republic of Kazakhstan, the unemployment rate in the country for July 2021 is $4.9 \%$. Russia has a similar situation with Kazakhstan.
In Kazakhstan, as in most countries of the world, the young community is faced with painful manifestations of anti COVID measures, in particular, the loss of a job or the difficulty of finding a job. The high level of youth unemployment increases social tension and causes political instability in society. The NEET generation in Kazakhstan is growing and puzzling. The ILO NEET Index is the proportion of young people (aged 15-28) who do not work, are not engaged in education or vocational training, are outside the education system and employment, and are a potential source of the youth labor market. According to the ILO methodology for 2020 , the indicator reached $7.7 \%$. The following Figure 3 shows the youth unemployment rate in Kazakhstan from 2016 to 2020, which also reveals an increase in the number of unemployed with the arrival of the emergency event.

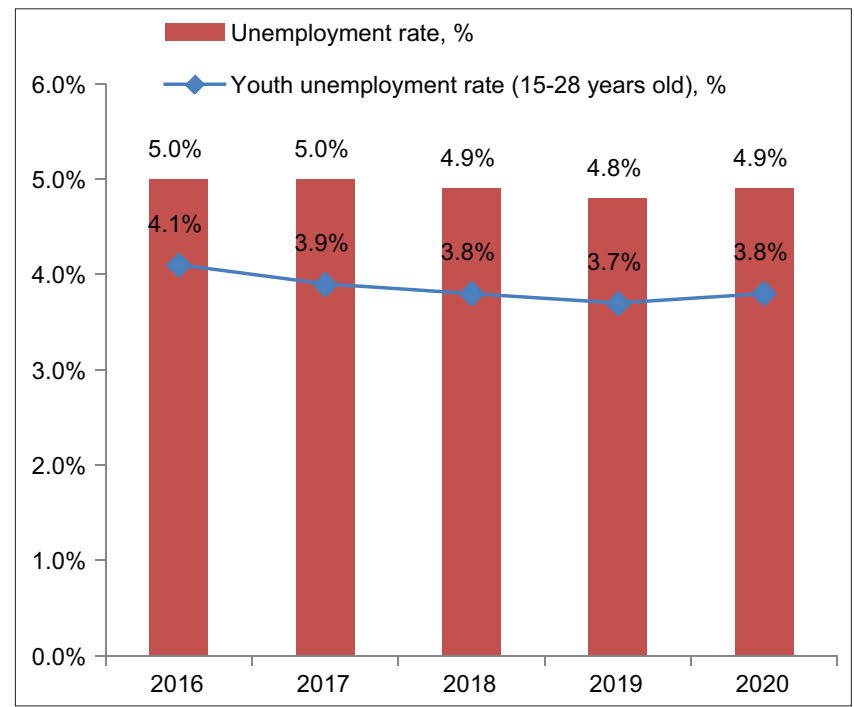

Figure 3: The level of youth unemployment in Kazakhstan from 2016 to 2020

"Leaders" are metropolises, such as NurSultan, Almaty, Shymkent, cities with a high influx of young people.

The level of education also plays a significant role in shaping the structure of employment. According to the results of a sociological survey among respondents, the distribution of the educational level of respondents and their parents depending on social status is presented in Figure 4. The regression analysis revealed a significant relationship between the social status and the level of education of respondents $(\beta=0.221, \mathrm{R} 2=0.0489$, $p<0.001(\beta=0.2149, R 2=0.0657, p<0.001)$. Moreover, the unemployed respondents were less satisfied with their education $(67 \%)$, while in other groups this indicator varied within $78-80 \%(p>0.05)$.

Least of all, people with incomplete higher, secondary and incomplete secondary education speak about full and stable employment. The unemployment rate is highest among those with incomplete secondary and general secondary education. For questions about 


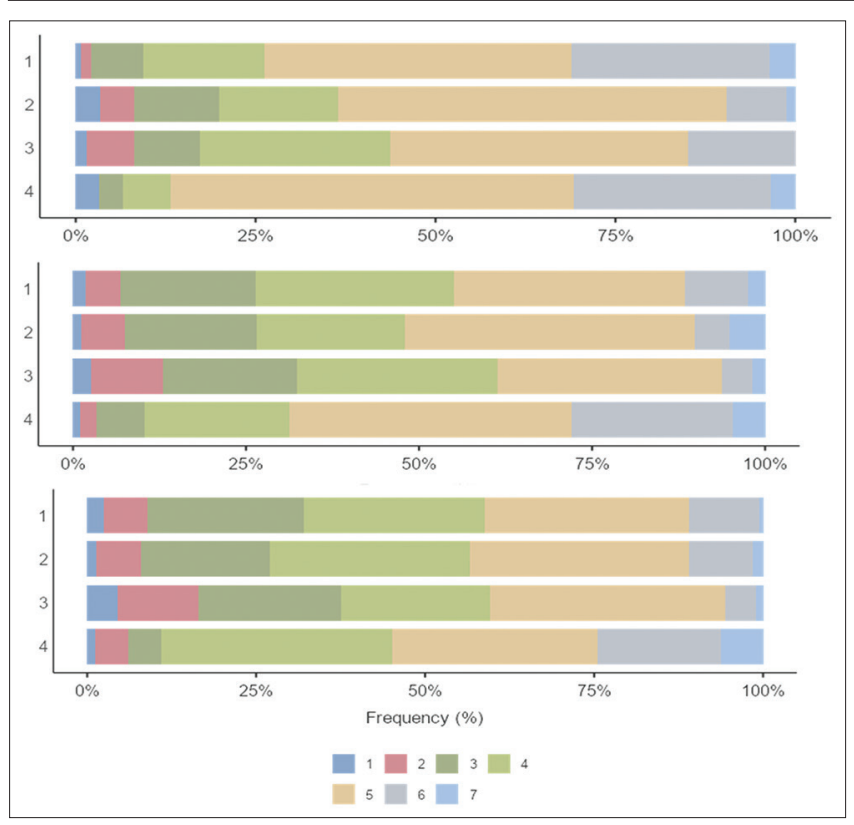

Figure 4: The level of education of respondents and their parents depending on social status

education, the following results were obtained: education of respondents, but not of their parents, was a predictor of hospitalization $(\beta=0.124, \mathrm{R} 2=0.0154, p=0.004)$, education of the mother but not the father was a predictor of social status $(\beta=0.132, \mathrm{R} 2=0.0239, p=0.019)$.

Table 2 presents data on the feeling of support from the state, family and relatives/friends among 4 groups of respondents by social status. Participants of the study who are not employed and not studying ( $n=125)$ feel social support significantly lower $(p<0.05)$. This is due to the fact that young people are required to provide financial support, from school they impose a specialty in which the future specialist either does not have the desire to work or does not have the ability.

Table 2: Distribution by feeling of support

\begin{tabular}{llll}
\hline Social status & \multicolumn{5}{l}{ Support from $(\%)$} & \\
\cline { 2 - 4 } & State $(\mathrm{n}=530)$ & Family $(\mathrm{n}=533)$ & Relatives/friends $(\mathrm{n}=532)$ \\
\hline Employed & $25 \%$ & $77.3 \%$ & $56.6 \%$ \\
Unemployed/student & $28 \%$ & $95.3 \%$ & $74.1 \%$ \\
Unemployed/not student & $18 \%$ & $76.0 \%$ & $53.6 \%$ \\
Employed/student & $23 \%$ & $88.9 \%$ & $70.0 \%$ \\
p-value & 0.006 & $<0.001$ & 0.009 \\
\hline
\end{tabular}

Unemployed youth more often noted health problems over the past year $(42.3 \%)$ than in other social groups (35.6-37.8\%), but this difference was not significant $(p=0.724)$. A similar situation was observed when assessing the incidence of chronic diseases $(p=0.365)$. However, unemployed respondents $(16.1 \%)$ were hospitalized more often in comparison with other groups (2.2-13.0\%), $p=0.010$. The distribution of such bad habits as smoking and alcohol consumption did not have a significant difference between the groups $(p=0.180)$.

About $35.5 \%$ of unemployed youth were not attached to polyclinics, while among other groups of the surveyed this indicator varied in the range of 9.0-19.1\%, while most of the attached respondents were among those employed $(p<0.001)$. Satisfaction with the provision of medical care was approximately the same among the study groups ( $p=0.881)$.

We raised the question of vaccination among the working and unemployed population, where the result determined that social status was a reliable predictor of vaccination $(\beta=-0.225, \mathrm{R} 2=0.0507$, $p<0.001)$. The smallest number of young people vaccinated against COVID-19 was unemployed respondents $(50 \%), p<0.001$.

According to the studied literature, the question of alcohol consumption was raised, where, according to the results of the survey, it turned out that social status was a reliable predictor of alcohol consumption $(\beta=-0.0908, \mathrm{R} 2=0.00824, p=0.037)$.

In the final part of the study, the respondents were asked to write the opinion about the existing difficulties of unemployed young people, where such answers as "ill-being disturbs family relations," "lack of jobs in the specialty, low wages and high living costs," "restrictions during the quarantine period influenced the search for work," "post-COVID made it difficult to work", "health problems do not allow finding a job," "job search is difficult and requires material costs" and other, which shows that young people have health difficulties and both before employment and as a result of its absence.

\section{Conclusions}

This study revealed limited opportunities in the search for information, medical information systems do not take into account the social status of young people. Young unemployed men and women are at higher risk of incidence compared to their working peers. The data show a strong positive association between unemployment and many adverse health effects. However, the answer to the question of whether unemployment causes these adverse effects is not so straightforward, since there are many indirect and confusing factors that can be social, economic or clinical. Many authors have proposed causal mechanisms, but further research is needed to test these hypotheses.

According to the results of a sociological survey, the majority of unemployed young people from urban areas have higher education, while none of the respondents surveyed is registered at the employment center. There are diseases such as disorders of musculoskeletal and respiratory system. Among the respondents, one thirds have bad habits, in particular, alcohol consumption prevails. The survey showed that the level of youth unemployment in the country is high, there are systemic reasons leading to this 
phenomenon, and there is also an impact on the health of young people.

The results of the study emphasize the need to take medical and social measures to prevent health losses and improve the quality of life of unemployed youth. Activities should also be aimed at promoting employment among the unemployed with chronic diseases.

\section{Acknowledgments}

All authors are grateful to the heads of medical organizations in the regions of Kazakhstan for supporting this study.

\section{Institutional Review Board Statement}

The study was conducted in accordance with the guidelines Declaration of Helsinki and approved by the Ethics Committee NJSC Astana Medical University.

\section{References}

1. Cheng GH, Chan DK, Au WT. Profiles of employability and their career and psychological implications among unemployed youth. Appl Res Qual Life. 2020;16:2205-19. https://doi. org/10.1007/s11482-020-09869-4

2. Granados JA, lonides EL. Population health and the economy: Mortality and the great recession in Europe. Health Econ. 2017;26(12):e219-35. https://doi.org/10.1002/hec.3495 PMid:28345272

3. Brydsten A, Hammarström A, San Sebastian M. The impact of economic recession on the association between youth unemployment and functional somatic symptoms in adulthood: A difference-in-difference analysis from Sweden. BMC Public Health. 2016;16:230. https://doi.org/10.1186/ s12889-016-2917-0

PMid:26944536

4. Shahidi FV, Muntaner C, Shankardass K, Quiñonez C, Siddiqi A. The effect of welfare reform on the health of the unemployed: Evidence from a natural experiment in Germany. J Epidemiol Community Health. 2020;74(3):211-8. https://doi.org/10.1136/ jech-2019-213151

PMid:31915239

5. Stauder J. Unemployment, unemployment duration, and health: Selection or causation? Eur J Health Econ. 2019;20(1):59-73. https://doi.org/10.1007/s10198-018-0982-2 PMid:29725787

6. Youth and COVID-19. Impacts on Jobs, Education, Rights and Mental Well-Being. Survey Report International Labour Organization; 2020. Available from: https://www.ilo.org/global/topics/youth-employment/

\section{publications [Last accessed on 2021 May 25].}

7. Moxon D, Bacalso C, Șerban AM, with support from AlexandruRudol Ciuciu and Violetta Duncan. The Social, Economic and Mental Health Impact of COVID-19 on Young People in Europe; 2021.

8. Group of World Bank. COVID-19 and Human Capital. Europe and Central Asia Region Economy Report, Fall; 2020. https:// doi.org/10.1596/978-1-4648-1643-7

9. An Update on the Youth Labour Market Impact of the COVID19 Crisis. Survey report International Labour Organization; 2021. Available from: https://www.lo.org/global/topics/youthemployment/publications/WCMS_753026/lang--en/index.htm

10. Monika Grzegorczyk and Guntram B. Wolff. The Scarring Effect of COVID-19: Youth Unemployment in Europe; 2020.

11. Impact of COVID-19 on Informal Workers, Rome; 2020. https:// doi.org/10.4060/ca8560ru

12. International Labour Organization (ILO). Global Employment Trends for Youth 2017. Paths to a Better Working Future. Geneva: International Labour Organization; 2017.

13. Youth Unemployment and Causes/MSG Management Study Guide. Available from: https://www.managementstudyguide.com/youthunemployment-and-causes.htm [Last accessed on 2021 May 25].

14. Kirillov PA, Sizonenko NN. Youth Unemployment as a Threat to the Social and Economic Stability of the State Young Scientist No. 18; 2020. p. 97-101.

15. Duisekova S, Turgambayeva A, Turgambayeva A, Zhanaliyeva M, Sarsenbayeva G, Mustafin A. Youth unemployment as a factor affecting the health. Iran J Public Health. 2020;49(6):1195-7.

16. Vancea $M$, Utzet $M$. How unemployment and precarious employment affect the health of young people: A scoping study on social determinants. Scand J Public Health. 2017;45(1):73-84. https://doi.org/10.1177/1403494816679555 PMid:27885160

17. Gajewski P, Zhukovska K. Short-run and long-run effects of unemployment on suicides: Does welfare regime matter? Eur J Public Health. 2017;27(6):1038-42. https://doi.org/10.1093/ eurpub/ckx180

PMid:29048496

18. Moore TH, Kapur N, Hawton K, Richards A, Metcalfe C, Gunnell D. Interventions to reduce the impact of unemployment and economic hardship on mental health in the general population: A systematic review. Psychol Med. 2017;47(6):1062-84. https:// doi.org/10.1017/S0033291716002944 PMid:27974062

19. Bartelink VH, Ya KZ, Guldbrandsson K, Bremberg $\mathrm{S}$ Unemployment among young people and mental health: A systematic review. Scand J Public Health. 2020;48(5):544-58. https://doi.org/10.1177/1403494819852847

PMid:31291827

20. Trading Economics/Молодежная Безработица-Список Стран; 2021. Available from: https://www.ru.tradingeconomics.com/countrylist/youth-unemployment-rate [Last accessed on 2021 May 25].

21. Janlert $U$. Unemployment as a disease and diseases of the unemployed. Scand J Work Environ Health. 1997;23 Suppl 3:79-83.

PMid:9456072

22. van Zon SKR, Reijneveld SA, Mendes de Leon CF, Bültmann U. The impact of low education and poor health on unemployment varies by work life stage. Int J Public Health. 2017;62(9):997-1006. https://doi.org/10.1007/s00038-017-0972-7 PMid:28421238

23. Pega F, Carter K, Blakely T, Lucas PJ. In-work tax credits for families and their impact on health status in adults. Cochrane Database Syst Rev. 2013;8:CD009963. https://doi. org/10.1002/14651858.CD009963.pub2 


\section{PMid:23921458}

24. Dooley D, Fielding J, Levi L. Health and unemployment. Annu Rev Public Health. 1996;17:449-65. https://doi.org/10.1146/ annurev.pu.17.050196.002313

PMid:8724235

25. Herbig $B$, Dragano $N$, Angerer $P$. Health in the long-term unemployed. Dtsch Arztebl Int. 2013;110(23-24):413-9. https:// doi.org/10.3238/arztebl.2013.0413

PMid:23837086

26. Wanberg CR. The individual experience of unemployment Annu Rev Psychol 2012;63:369-96. https://doi.org/10.1146/ annurev-psych-120710-100500

PMid:21721936

27. Chinekesh A, Hoseini SA, Mohammadi FS, Motlagh ME, Eftekhari MB, Ardalan G, et al. Factors affecting social health from young adults' perspective: A qualitative study. Int J Prev Med. 2019;10:146. https://doi.org/10.4103/ijpvm.IJPVM_13_18 PMid:31579139

28. Vanthomme K, Gadeyne S. Unemployment and cause-specific mortality among the Belgian working-age population: The role of social context and gender. PLoS One. 2019;14(5):e0216145. https://doi.org/10.1371/journal.pone.0216145 PMid:31048926

29. Doku DT, Acacio-Claro PJ, Koivusilta L, Rimpelä A. Health and socioeconomic circumstances over three generations as predictors of youth unemployment trajectories. Eur J Public Health. 2019;29(3):517-23. https://doi.org/10.1093/eurpub/cky242 PMid:30476022

30. Huffman AH, Culbertson SS, Wayment HA, Irving LH. Resource replacement and psychological well-being during unemployment: The role of family support. J Vocat Behav. 2015;89:74-82. https://doi/10.1016/j.jvb.2015.04.011

31. Roos E, Lahelma E, Saastamoinen P, Elstad JI. The association of employment status and family status with health among women and men in four Nordic countries. Scand J Public Health. 2005;33:250-60. https://doi.org/10.1080/14034940510005680 PMid: 16087487

32. Yildiz B, Schuring M, Knoef MG, Burdorf A. Chronic diseases and multimorbidity among unemployed and employed persons in the Netherlands: A register-based cross-sectional study. BMJ Open. 2020;10(7):e035037. https://doi.org/10.1136/ bmjopen-2019-035037

PMid:32616488

33. Yildiz B, Burdorf A, Schuring $M$. The influence of chronic diseases and multimorbidity on entering paid employment among unemployed persons-a longitudinal register-based study. Scand J Work Environ Health. 2021;47(3):208-16. https:// doi.org/10.5271/sjweh.3942

PMid:33350454

34. McKee-Ryan F, Song Z, Wanberg CR, Kinicki AJ. Psychological and physical well-being during unemployment: A metaanalytic study. J Appl Psychol. 2005;90(1):53-76. https://doi. org/10.1037/0021-9010.90.1.53

PMid: 15641890

35. Fryer D. Unemployment and mental health: Hazards and challenges of psychology in the community. In: Isaksson $\mathrm{K}$, Hogstedt C, Eriksson C, Theorell T, editors. Health Effects of the New Labour Market. Boston: Springer; 2002. p. 11-23. https:// doi.org/10.1007/0-306-47181-7_3

36. Ronchetti J, Terriau A. Impact of unemployment on selfperceived health: Evidence from French panel data. Eur J Health Econ. 2019;20(6):879-89. https://doi.org/10.1007/ s10198-019-01050-5

PMid:30963349
37. Schuring M, Robroek SJ, Burdorf A. The benefits of paid employment among persons with common mental health problems: Evidence for the selection and causation mechanism. Scand J Work Environ Health. 2017;43(6):540-9. https://doi. org/10.5271/sjweh.3675 PMid:28967666

38. Ford E, Clark C, McManus S, Jenkins R, Bebbington P, Brugha T, et al. Common mental disorders, unemployment and welfare benefits in England. Public Health. 2010;124(12):675-81. https:// doi.org/10.1016/j.puhe.2010.08.019

PMid:21035154

39. Zuelke AE, Luck T, Schroeter ML, Witte AV, Hinz A, Engel C, et al. The association between unemployment and depressionResults from the population-based LIFE-adult-study. J Affect Disord. 2018;235:399-406. https://doi.org/10.1016/j. jad.2018.04.073

PMid:29677604

40. Álvaro JL, Garrido A, Pereira CR, Torres AR, Barros SC. Unemployment, self-esteem, and depression: Differences between men and women. Span J Psychol. 2019;22:E1. https:// doi.org/10.1017/sjp.2018.68

PMid:30813974

41. Mamun MA, Akter S, Hossain I, Faisal MT, Rahman MA, Arefin A, et al. Financial threat, hardship and distress predict depression, anxiety and stress among the unemployed youths: A Bangladeshi multi-city study. J Affect Disord. 2020;276:1149-58. https://doi. org/10.1016/j.jad.2020.06.075

PMid:32791351

42. van Rijn RM, Carlier BE, Schuring M, Burdorf A. Work as treatment? The effectiveness of re-employment programmes for unemployed persons with severe mental health problems on health and quality of life: A systematic review and meta-analysis. Occup Environ Med. 2016;73(4):275-9. https://doi.org/10.1136/ oemed-2015-103121 PMid:26740687

43. van der Noordt M, IJzelenberg H, Droomers M, Proper KI. Health effects of employment: A systematic review of prospective studies. Occup Environ Med. 2014;71(10):730-6. Https://doi. org/10.1136/oemed-2013-101891 PMid:24556535

44. Khlat M, Sermet C, Le PapeA. Increased prevalence of depression, smoking, heavy drinking and use of psycho-active drugs among unemployed men in France. Eur J Epidemiol. 2004;19(5):445-51. https://doi.org/10.1023/b: ejep.0000027356.71414.bd PMid: 15233317

45. Tapia Granados JA, Christine PJ, Ionides EL, Carnethon MR, Diez Roux AV, Kiefe $\mathrm{Cl}$, et al. Cardiovascular risk factors, depression, and alcohol consumption during joblessness and during recessions among young adults in CARDIA. Am J Epidemiol. 2018;187(11):2339-45. https://doi.org/10.1093/aje/ kwy 127 PMid:29955769

46. Thern E, Ramstedt M, Svensson J. Long-term effects of youth unemployment on alcohol-related morbidity. Addiction. 2020;115(3):418-25. https://doi.org/10.1111/add.14838 PMid:31618497

47. Popovici I, French MT. Does unemployment lead to greater alcohol consumption? Ind Relat (Berkeley). 2013;52(2):444-66. https://doi.org/10.1111/irel.12019 PMid:23543880

48. Pedron S, Emmert-Fees K, Laxy M, Schwettmann L. The impact of diabetes on labour market participation: A systematic review of results and methods. BMC Public Health. 2019;19:25. https:// doi.org/10.1186/s12889-018-6324-6

PMid:30616606 
49. Leal J, Luengo-Fernández R, Gray A, Petersen S, Rayner M. Economic burden of cardiovascular diseases in the enlarged European Union. Eur Heart J. 2006;27(13):1610-9. https://doi. org/10.1093/eurheartj/ehi733

PMid:16495286

50. Schofield DJ, Callander EJ, Shrestha RN, Passey ME, Percival R, Kelly SJ. Multiple chronic health conditions and their link with labour force participation and economic status. PLoS One. 2013;8(11):e79108. https://doi.org/10.1371/journal. pone.0079108
PMid:24223887

51. Mokona H, Yohannes $\mathrm{K}$, Ayano G. Youth unemployment and mental health: Prevalence and associated factors of depression among unemployed young adults in Gedeo zone, Southern Ethiopia. Int J Ment Health Syst. 2020;14:61. https://doi. org/10.1186/s13033-020-00395-2

52. Kieselbach T. Youth unemployment and health effects. Int J Soc Psychiatry. 1988;34(2):83-96. https://doi. org/10.1177/002076408803400201

PMid:3045042 